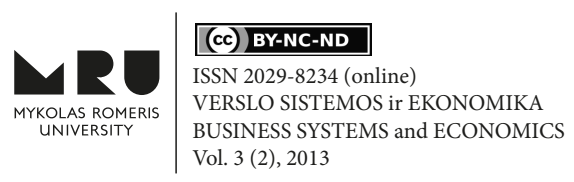

\title{
SHADOW ECONOMY IN UKRAINE: MODELLING AND ANALYSIS
}

\author{
Igor VINNYCHUK \\ Yurii Fedkovych Chernivtsi National University \\ 2 Kotsjubynskyi Str., Chernivtsi 58012, Ukraine \\ E-mail: i.vinnychuk@chnu.edu.ua \\ Serhii ZIUKOV \\ Yurii Fedkovych Chernivtsi National University \\ 2 Kotsjubynskyi Str., Chernivtsi 58012, Ukraine \\ E-mail:s.zyukov@chnu.edu.ua \\ doi:10.13165/VSE-13-3-2-01
}

\begin{abstract}
This paper provides an analysis of the size and development of the shadow economy in Ukraine. The shadow economy is defined as a system of interconnected relationships that take place outside the existing laws and do not allow direct and regular statistical accounting and tax control. Insufficient quality of state institutions, ineffective regulatory policy, imperfection of the tax system, unformed competitive environment and corruption are the driving forces for the shadow economy. The paper identifies the socio-economic consequences arising from the functioning of the shadow economy. Economic-mathematical model was constructed to identify patterns of shadow economy functioning. Economic-mathematical analysis allows formulating a list of proposals on ways and means of reducing the size of the shadow economy in Ukraine.
\end{abstract}

Keywords: shadow economy, Ukraine, corruption.

JEL classification: O17, E26.

\section{Introduction}

Negative expectations of economic entities and macroeconomic instability during the crisis caused activation of the capital outflow from the legal sector and the growing of the Ukraine's shadow economy, which in the pre-crisis period tended to decrease. On the one hand, shadow economy relations mitigate crisis impacts. Through these relationships, economic entities have adapted their behavior in accordance with emerging risks. On the other hand, a high level of shadow economy objectively leads to management destruction of economy, further stratification of the population, decreasing of the confidence to the government and deceleration of reforms. In this regard, the reduction of the shadow economy is an integral part of the reform strategy. 
Priority directions for reducing the shadow economy are the legalization of shadow financial flows, the legalization of the labor and land markets and the combat against corruption. Creating by government such conditions, under which staying in the informal sector is too expensive and risky for entities, it would motivate for doing legal business.

Reducing the size of the shadow economies is one of the biggest problems for lots of countries all over the world. There are many scientific researches, which include some ways of reducing of shadow economy's level.

In fact, Putnins and Sauka (2011) suggest that to reduce the size of the shadow economies by encouraging voluntary compliance, a key factor that needs to be addressed is the high level of dissatisfaction with the tax system and government. Addressing this issue could involve actions, such as making tax policy more stable and increasing the transparency, with which taxes are spent.

Giles (1999) and Dell'Anno (2003) found out, that the tax burden is one of the main causes for the existence of the shadow economy. Schneider and Klingmair (2004) showed that even major tax reforms with major tax rate deductions would not lead to a substantial decrease of the shadow economy.

The present research was made for the Ukrainian economy to find out alternative ways how to reduce the size of the shadow economy in Ukraine. Reducing the shadow economy allows fully implement reforms aimed at modernizing and improving the competitiveness of Ukraine.

\section{The shadow economy in Ukraine}

The shadow economy acts as a threat to economic security, negatively affects the development of the national economy. The main effects of the shadow economy are collapse, economic crisis, destruction of business relationships, the decline in production, the growth of economic crime. In the social sphere, shadow economy has led to a sharp differentiation, stratification of society into the rich and the poor, to orientation large part of society, including middle class, on generating income by any means.

In recent years, a tendency of reducing the level of shadow economy has been observed (see Figure 1). According to official data of the Ministry of Economic Development and Trade of Ukraine, the level of shadow economy is $34 \%$ of the official GDP (MEDT of Ukraine, 2012). However, researcher of renowned specialist in the field of the shadow economy Friedrich Schneider showed that the level of shadow economy is $44 \%$ of the GDP (Schneider, 2012). Despite the positive trend of reducing the shadow economy, there are a number of potential risks that may contribute to growing of the shadow economy. First of all, they are associated with a possible recession in the EU and significant financial commitments of Ukraine on foreign markets, leading to a sharp slowdown in economic growth of Ukraine. 
Figure 1: The level of the shadow economy in Ukraine

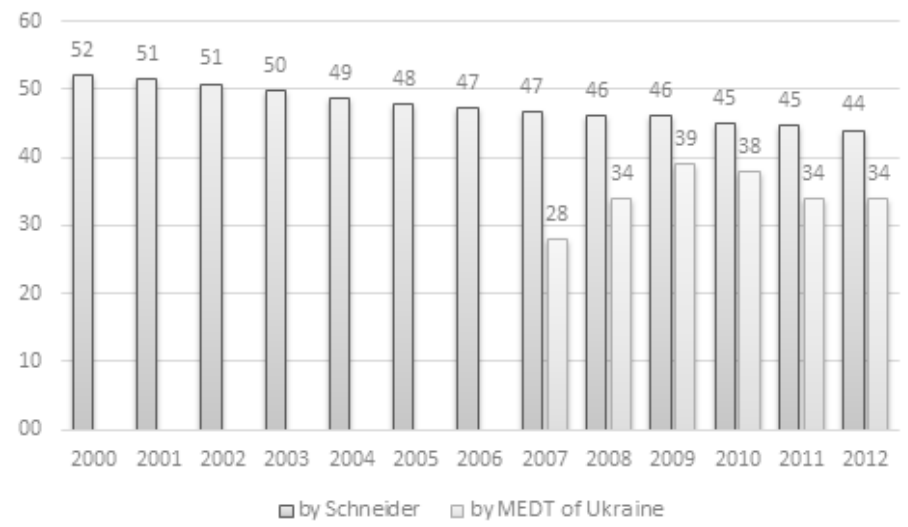

Source: Schneider (2012), Ministry of Economic Development and Trade of Ukraine (2012)

The level of the shadow economy in Ukraine is the highest in Europe (see Figure 2).

Figure 2: The level of the shadow economy in EU countries and Ukraine

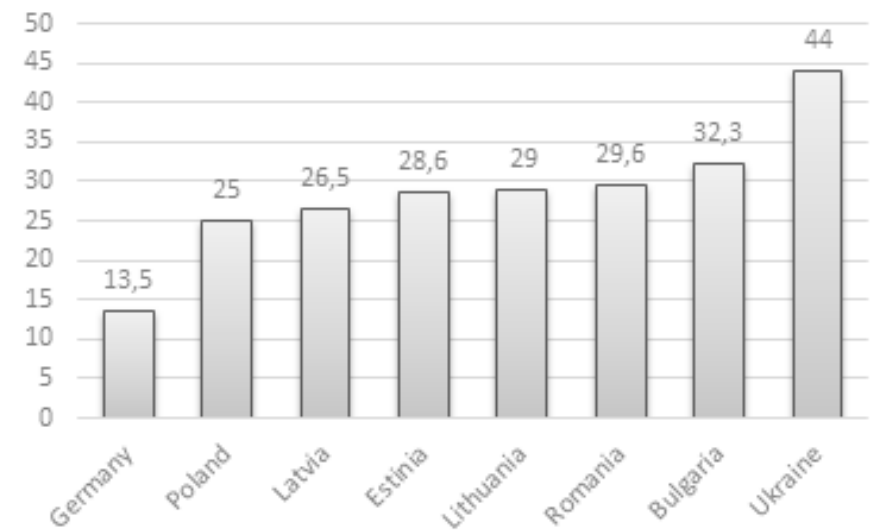

Source: Schneider (2012)

\section{The negative effects of the shadow economy in Ukraine}

The negative effects of shadow and criminal economic activity manifested in various social and economic strains include the following (Bekryashev and Beloserov, 2000):

1. Deformation of tax field finds expression in influencing the distribution of the tax burden and, as a result, the reduction of budget expenditures and deformation of its structure. The current tax system negatively affects the profitability. The results of ill-conceived tax policy are defaults increment, increased taxation of law-abiding citizens, periodic de- 
lays in salary payments, increasing differentiation of incomes and living standards between governing agencies, the administration of companies and their workers (Kovalenko, 1999).

The uneven tax burden on different sectors of the economy creates incentives of reallocating resources in the speculative sector. In international rankings for transparency and ease of doing business “Doing Business 2013", Ukraine was ranked 137th among 185 countries (see Table 1).

Table 1: Doing Business rank of transparency and ease of doing business

\begin{tabular}{|l|r|r|r|r|r|}
\hline \multicolumn{1}{|c|}{ Economy } & $\begin{array}{c}\text { Ease of Doing } \\
\text { Business Rank }\end{array}$ & $\begin{array}{c}\text { Starting a } \\
\text { Business }\end{array}$ & $\begin{array}{c}\text { Dealing with } \\
\text { Construction Permits }\end{array}$ & $\begin{array}{c}\text { Getting } \\
\text { Credit }\end{array}$ & $\begin{array}{c}\text { Protecting } \\
\text { Investors }\end{array}$ \\
\hline Germany & 20 & 106 & 14 & 23 & 100 \\
\hline Estonia & 21 & 47 & 35 & 40 & 70 \\
\hline Latvia & 25 & 59 & 113 & 4 & 70 \\
\hline Lithuania & 27 & 107 & 161 & 53 & 4 \\
\hline Poland & 55 & 124 & 123 & 40 & 49 \\
\hline Bulgaria & 66 & 57 & 129 & 12 & 49 \\
\hline Romania & 72 & 68 & 183 & 23 & 117 \\
\hline Ukraine & 137 & 50 & & & 48 \\
\hline
\end{tabular}

Source: International Bank for Reconstruction and Development/The World Bank (2013)

One of the components of this index is the sub-index "Paying Taxes", according to which Ukraine has improved its position by 18 points and was ranked in 165th place (see Table 2).

Due to tax reform in Ukraine, the level of tax burden, and the number and duration of payments are gradually reduced.

Particularly, through the adoption and entry into force of certain provisions of the Tax Code of 02.12.2010 № 2755-VI and other regulations of tax payments per year 28 against 135 payments were reduced in the previous period.

In addition, due to the implementation of filing tax reports to the state tax authority only in electronic form for taxpayers belonging to large and medium enterprises, the duration of the process of paying taxes in Ukraine has been reduced by 166 hours up to 491 hours per year.

According to the tax code, tax rate was changed and, as a result, according to the "Doing Business" ranking, total tax rate decreased to $55.4 \%$ versus $57.1 \%$.

Table 2: Most countries in accordance with sub-index "Paying Taxes"

\begin{tabular}{|l|r|r|r|r|r|r|r|}
\hline Economy & Rank & $\begin{array}{c}\text { Payments } \\
\text { (number per } \\
\text { year) }\end{array}$ & $\begin{array}{c}\text { Time } \\
\text { (hours } \\
\text { per year) }\end{array}$ & $\begin{array}{c}\text { Profit tax } \\
(\%)\end{array}$ & $\begin{array}{c}\text { Labor tax and } \\
\text { contributions } \\
(\%)\end{array}$ & $\begin{array}{c}\text { Other } \\
\text { taxes } \\
(\%)\end{array}$ & $\begin{array}{c}\text { Total tax } \\
\text { rate (\% } \\
\text { profit) }\end{array}$ \\
\hline Ukraine & 165 & 28 & 491 & 11.6 & 43.1 & 0.7 & 55.4 \\
\hline Estonia & 50 & 8 & 85 & 8 & 39.4 & 19.8 & 67.3 \\
\hline Lithuania & 60 & 11 & 175 & 5.9 & 35.1 & 2.8 & 43.7 \\
\hline Latvia & 52 & 7 & 264 & 4.8 & 27.3 & 4.6 & 36.6 \\
\hline Germany & 72 & 9 & 207 & 18.9 & 21.9 & 5.9 & 46.8 \\
\hline Poland & 114 & 18 & 286 & 17.4 & 23.8 & 2.6 & 43.8 \\
\hline Bulgaria & 91 & 15 & 454 & 4.8 & 20.2 & 3.7 & 28.7 \\
\hline Romania & 136 & 41 & 216 & 10.5 & 31.5 & 2.2 & 44.2 \\
\hline
\end{tabular}

Source: International Bank for Reconstruction and Development/The World Bank (2013) 
2. Impact on monetary sphere is manifested in the structure deformation of payments, boosting inflation, deformation of credit relations and increasing investment risks, damage to credit institutions, investors, depositors, shareholders and society in general.

Illegal activities in the financial and banking systems are associated with abuses in the granting of credit, loans, illegal conversion of funds, illegal bank securities issuance, credit and fiscal funds despoliation by falsifying enterprises financial data, mortgaged property (for its price or availability), application of the fraudulent bankruptcy. According to State Tax Administration (STA), more than a half of a real net profit of financial institutions consist of the shadow component (Chyzhov, 2010).

An important feature of the situation is the active use of the banking system for the legalization of funds obtained by criminal means. Implementation of monitoring suspicious financial transactions promotes positive change in this direction.

In the illegal sector, there is actively used cash circulation. Over the last five years, the amount of money outside banks has increased four times. Moreover, in Ukraine, according to representatives of the National Bank, cash revolves to 20 billion USD (Okhrimenko, 2010).

3. Influence on the investment process is one of the most significant results of shadow activities impact on economic development. The high level of shadow economy reduces international investors' confidence in the country.

In terms of strength of investor protection under the Global Competitiveness Index, Ukraine is ranked 94th among 144 countries in the world, which does not make Ukraine more attractive to foreign investors (World Economic Forum, 2013).

4. Impact on the environment. Criminal organizations may inflict serious environmental damage, especially in underdeveloped countries.

Modern poaching increases avalanche manner and is a serious threat to the national security of Ukraine, e.g., in 1966, Ukraine detained 15 thousand fish poachers, in 1975 - 30 thousand, and in 2007 - already 96.6 thousand fish poachers (Boreyko, 2010). First of all, the increasing number of poachers was associated with a low probability of punishment. In particular, in 2006, from 9500 arrested poachers only 3 were held criminally liable and the amount of fines by an average of one poacher was only 4 USD.

World illegal deforestation brings criminals approximately 10-15 billion USD. In Ukraine, illegal deforestation also has gained considerable popularity. In 2009, state forestry enterprises submitted 797 cases of illegal logging to the law enforcement agencies, which resulted in damage to state, in amount of 2 million USD, in the first quarter of $2010-177$ cases with damage on the level of 1 million USD (Boreyko, 2010).

5. Impact on the country's political system. This effect at the state level is manifested mainly through interests lobbying by government institutions.

According to The Global Competitiveness Index, in 2012 Ukraine was ranked 73rd among 144 countries of the world (World Economic Forum, 2012). Taking into account characteristics such as market size and solid educational system, Ukraine is ranked in pretty high places; the situation of the institutional development of Ukraine is the main problem. Arguably, the country's most important challenge is the needed overhaul of its institutional framework, which cannot be relied on because it suffers from red tape, lack of transparency and favoritism.

By "Institutes" component, Ukraine is ranked 132nd among 144 countries. This is due to the extremely low estimated situation in the field of protection of minority owners (141 seats), the effectiveness of the legislative bodies in the regulatory area (141 seats), the pro- 
tection of property rights (134), independence of the judiciary (124), the burden of government regulation (135), trust in the police (122), efficiency of legal framework in challenging regs (139), wastefulness of government spending (128), irregular payments and bribes (133), etc. (World Economic Forum, 2012).

6. The impact on the effective state functioning. The main negative influence of the shadow economy on the effectiveness of the state is shown in the increasing corruption in all functional subsystems of the state apparatus.

Corruption was and remains one of the biggest obstacles on the way to reform Ukraine's economy. Corruption threatens the very existence of the state; it is the main obstacle to improving living standards, economic development, civil society, the combat against organized crime. The development of corruption in Ukraine is a major obstacle to attracting foreign investment and advanced technologies in the economy.

Ukraine faces a deteriorating corruption, says an international organization "Transparency International" - global coalition against corruption. According to the Corruption Perception Index (CPI), which measures the level of perception of corruption in the public sector and is based on a survey among experts and the business community, in 2012 Ukraine received 26 points, thus finishing among 176 countries surveyed in a "honorary” position 144 (Transparency International, 2012) (see Table 3).

Table 3: Corruption Perception Index

\begin{tabular}{|l|r|r|}
\hline \multicolumn{1}{|c|}{ Country } & Place & \multicolumn{2}{c|}{ Score } \\
\hline Germany & 13 & 79 \\
\hline Poland & 41 & 58 \\
\hline Latvia & 54 & 49 \\
\hline Estonia & 32 & 64 \\
\hline Lithuania & 48 & 54 \\
\hline Romania & 66 & 44 \\
\hline Bulgaria & 75 & 41 \\
\hline Ukraine & 144 & 26 \\
\hline
\end{tabular}

Source: Transparency International (2012)

Ukrainian experts believe that, in general, the report objectively reflects the status of the corruption combat in Ukraine. Terms of political crisis are unfavorable to solve problems and acute political confrontation may facilitate resolution only to individual cases, but not the problem altogether.

However, leaders of law enforcement agencies follow a completely different perspective. In 2010, courts received 17,980 reports of corruption, of which only 8,831 persons were brought to justice. According to the General Department of Civil Service of Ukraine (GDCS of Ukraine), there were 367,308 civil servants on December 31, 2012 in Ukraine. After reviewing the corruption reports in 2010 , only 127 people were fired $(0.02 \%$ of the total number of retired civil servants in 2010) (GDCS of Ukraine, 2012).

The analysis showed the presence of the shadow economy's negative impact on the economic situation in the country. For a more detailed analysis of this phenomenon, it is advisable to use tools of economic and mathematical modeling. 


\section{Model of legal and shadow economies interaction}

Consider one of the simplest models of functioning of legal and shadow economies. They are connected with the economic structure of society, when it refers to the distribution of citizens, their families, etc., for liquid accumulation (savings) in cash and securities that are convertible into cash quickly. In the simplest case, the aggregate economy that produces a single aggregate social product can be considered.

The social groups of capital owners and real employees (workers) could be considered next. Thus, it is assumed that the number of workers and owners equals to $n_{1}$ and $n_{2}$. Shadow economy means that at the same time both owners and workers can be involved in the legal and in the informal sector. Within this model, other variants of workers and owners interaction in legal and shadow economies are not considered. It is assumed that the members of each group are equal in their capital (savings) $x_{i}(i=\overline{1,2})$, which usually depends on aggregate demand and supply of products (goods) on the market.

The demand function described by a single buyer demand, which depends on its financial capacity, which in turn is determined by its savings and price. If $p$ is a price, then $\mu=\frac{x}{p}$ is the purchasing power of the buyer, and $G=G(\mu)=G(x / p)$ is the demand function. For problems formulated in this paper, the already tested in practice demand function can be chosen, which is described by Chernavskii [Chernavskii et al., 2002].

If $n$ workers are involved in the aggregate product's production and $\mu=\frac{x}{p}$ is the fi-

nancial capacity of production, $\frac{\propto}{n}$ is production capacity, then $F=F\left(\frac{\mu}{n}\right)$ is production function. Specifications of function $F=F\left(\frac{\mu}{n}\right)$ can also be selected in various ways, but in each case the function should reflect the fundamental laws of production.

In order to build a model of the legal $(L)$ and shadow $(S)$ economies functioning, it can be assumed that the workers as consumers spend a fraction $\alpha_{1}$ of their savings for the consumption in the legal sector and a fraction $\beta_{1}$ - for the consumption in the shadow economy $\left(\alpha_{1}+\beta_{1} \leq 1\right)$. Similarly, business owners spend fraction $\alpha_{2}$ and $\beta_{2}$ of their savings according to the consumption in legal and shadow sectors. In addition, owners spend fraction $\delta_{2}$ of their savings on production needs in the legal sector and $\gamma_{2}$ - on production needs in the shadow sector $\left(\alpha_{2}+\beta_{2}+\delta_{2}+\gamma_{2} \leq 1\right)$. It is also assumed that $p_{L}$ is a price for products in sector $L, p_{S}$ is a price for products in sector $S$. So, if it is assumed that all the owners $\left(n_{2}\right)$ and all the workers $\left(n_{1}\right)$ are simultaneously involved in both sectors $(L$ and $S)$, the number of products produced by one worker in the legal sector is determined by the $F\left(\frac{n_{2} \delta_{2} x_{2}}{n_{1} p_{L}}\right)$ and the number of products produced by one worker in the shadow sector is determined by the $F\left(\frac{n_{2} \gamma_{2} x_{2}}{n_{1} p_{S}}\right)$. 
In addition, it should be noted that in the legal sector $L$ owner pays tax on gross payroll (rate $k_{L}^{*}$ ) and value added tax (rate $k_{L}^{* *}$ ), and in the shadow sector $S$ (it is assumed that taxes are similar, but have different meanings) the owner pays tax on shadow gross payroll $\left(\right.$ rate $k_{S}^{*}$ ) and the shadow value added tax (rate $k_{S}^{* *}$ ). The workers get wage in physical units: $r_{L}$ units in the sector $L$ and $r_{S}$ units in the sector $S . k_{L}$ and $k_{S}$ are income tax rates in legal and shadow sectors.

The dynamics of worker's savings change can be displayed by the following equation:

$$
\frac{d x_{1}}{d t}=p_{L}\left[r_{L}\left(1-k_{L}\right)-G\left(\frac{\alpha_{1} x_{1}}{p_{L}}\right)\right]+p_{S}\left[r_{S}\left(1-k_{S}\right)-G\left(\frac{\beta_{1} x_{1}}{p_{S}}\right)\right] \text {. }
$$

Obviously, equation (1) can be written as:

$$
\frac{d x_{1}}{d t}=p_{L} r_{L}\left(1-k_{L}\right)+p_{S} r_{S}\left(1-k_{S}\right)-p_{L} G\left(\frac{\alpha_{1} x_{1}}{p_{L}}\right)-p_{S} G\left(\frac{\beta_{1} x_{1}}{p_{S}}\right) \text {. }
$$

The dynamics of owner's savings depend on the total income from sales of legal and shadow products, taxes and total expenditure on worker's wages, production needs and taxation in the $L$ and $S$ sectors:

$$
\begin{aligned}
& \frac{d x_{2}}{d t}=\frac{p_{L}}{n_{2}}\left(1-k_{L}\right) \sum_{i=1}^{2} n_{i} G\left(\frac{\alpha_{i} x_{i}}{p_{L}}\right)+\frac{p_{S}}{n_{2}}\left(1-k_{S}\right) \sum_{i=1}^{2} n_{i} G\left(\frac{\beta_{i} x_{i}}{p_{S}}\right)-p_{L} G\left(\frac{\alpha_{2} x_{2}}{p_{L}}\right)- \\
& -p_{S} G\left(\frac{\beta_{2} x_{2}}{p_{S}}\right)-\frac{p_{L}}{n_{2}}\left[n_{1} r_{L}\left(1+k_{L}^{*}\right)+n_{1}\left(\lambda_{L}+k_{L}^{* *}\right) F\left(\frac{n_{2} \delta_{2} x_{2}}{n_{1} p_{L}}\right)\right]-
\end{aligned}
$$

Not only savings $x_{1}, x_{2}$, but also prices $p_{L}, p_{S}$ are dynamic variables. The dynamic of legal product's price is proportional to the difference between total demand and total supply of these products in the market, so the equation for the price $p_{L}$ has this form:

$$
\frac{d p_{L}}{d t}=v_{L}\left[\sum_{i=1}^{2} n_{i} G\left(\frac{\alpha_{i} x_{i}}{p_{L}}\right)-n_{1} F\left(\frac{n_{2} \delta_{2} x_{2}}{n_{1} p_{L}}\right)\right],
$$

where $v_{L}$ - inertia coefficient of the legal market.

Similarly, the dynamic of the shadow price is proportional to the difference between total demand and total supply of shadow products on the market:

$$
\frac{d p_{S}}{d t}=v_{S}\left[\sum_{i=1}^{2} n_{i} G\left(\frac{\beta_{i} x_{i}}{p_{S}}\right)-n_{1} F\left(\frac{n_{2} \gamma_{2} x_{2}}{n_{1} p_{S}}\right)\right],
$$

where $v_{S}$ - inertia coefficient of the shadow market.

The system of differential equations [1] - [4] can be expanded by initial conditions, such as the time $t=0$, i.e. conditions:

$$
x_{1}(0)=x_{1}^{(0)}, x_{2}(0)=x_{2}^{(0)}, p_{L}(0)=p_{L}^{(0)}, p_{S}(0)=p_{S}^{(0)}
$$

It obtains the relation [1] - [5], which formalizes the model of legal and shadow economies interaction $\left\{x_{1}, x_{2}, p_{L}, p_{S}\right\}$. 
The experiments with the model show that the emergence of the shadow economy slows down the income growth of workers. The delay of this growth reflects the typical economic slowdown, and its duration is directly related to the shadow exchange. The emergence of the shadow sector in transition economies also strongly affects the financial position of highly skilled professionals, for whom there is no employment in the informal labor market. In addition, the experiments with the model shows that only a complete economic revitalization reduces the shadow sector.

Reducing the shadow economy

To reduce the shadow economy, a comprehensive action needs to be conducted to improve the economy and the state apparatus, including the three main groups of factors that influence the development of the shadow economy:

- economic (level of taxation, high inflation, etc.);

- social (high unemployment, low living standards, sharp differentiation in profits);

- legal (inadequate legislation, inadequate training of law enforcement personnel to work in the new economic environment, low level of legal awareness and legal culture of the population).

The experience of developed countries shows that the choice of indirect methods nature (improving tax and labor laws, social security, training and retraining) compared to administrative measures (bans, increasing penalties, licenses, contracts) is more efficient to combat the shadow economy (Varnaliy and Goncharuk, 2006).

In order to legalize the economy during the years 2011-2012, Ukrainian authorities took measures in the following areas, improving the investment climate, reducing fiscal and regulatory pressure:

1. In order to complete a comprehensive reform of the tax system, Tax Code of Ukraine was adopted, which regulates relations arising in the area of taxes and fees, sets out the principles of the tax system, the list of taxes and duties (mandatory payments) payable to the budgets of all levels.

Tax Code of Ukraine came into force on January 1, 2011, so that was provided to reduce the tax burden (including through gradual reduction of income tax rates and the introduction of "tax holidays" for certain types of economic activity) and the introduction of automatic reimbursement of value added tax compliant taxpayers and state responsibility for its failure to redress (Verkhovna Rada of Ukraine, 2011).

2. Towards the prevention of corruption, The Law of Ukraine "On Principles of Prevention and Combating Corruption" was accepted. This law is the result of revision by the National Anti-Corruption Committee package of anti-corruption laws, making them controversial provisions into conformity with the Constitution of Ukraine, taking into account suggestions made by the Group of States against Corruption of the Council of Europe.

Given the fact that the shadow economy is the main source of livelihood of large sections of the population of Ukraine, today one-sided approach to the problems of shadow economy should be avoided and losses should be taken into account, which would be suffered by the population of Ukraine in case of enhanced reduction in the shadow areas. Thus, today the fundamental weight acquire such methods of legalization of the shadow economy, which guarantee the preservation of human potential in Ukraine by improving the efficiency and profitability of legal products and the increase of the basis of the jobs number and raise real incomes. 
Therefore, the main priorities of economic policy in Ukraine, which will legalize the Ukrainian shadow economy in strategic terms, include the following:

1. Stimulation investment processes. The need to develop tax incentives for investment use of credit resources of commercial banks, exempt from taxation companies' revenue that is spent on investment.

2. Control of regularity, completeness and timeliness of wages payments indexation, social contributions. In order to maintain the level of income, this would reduce the propensity for activities in the informal sector, possible use of non-cash settlements with the population, in particular for utilities.

3. Transparent and accessible mechanisms lending to the real sector of the economy and solving payment crisis.

4. Increasing professionalism of enterprises management in Ukraine, providing guidance and legal assistance in the preparation of business plans, investment projects, which will ensure the most efficient use of enterprises resources.

5. Strengthening public oversight of public funds, loans and foreign investment.

\section{Conclusion}

Solving the problem of shadow economy requires concerted efforts of the state in many areas of public policy. There is a need to move away from the assumption that legalization of shadow economy does not require special efforts and activities and will continue with the development of market relations in the country. Taking into account that the public sector needs reforms, without considering the impact of the shadow economy, they include performance risks.

The strategic priorities of legalizing Ukraine's economy at the present stage is stimulation of investment processes, improving the monetary policy, creating favorable conditions for business development, significant reduction and equalization of the tax burden, simplifying the tax system, strengthening tax control in terms of production costs, efficient management of the public sector of economy, increased state oversight of public funds, loans and foreign investment, counteraction to laundering of proceeds from crime, etc.

An important strategic priority in reducing the shadow economy level is strengthening the combat against corruption. To improve the quality of the combat against corruption, the following steps should be done: continuing the development of the judiciary, taking actions to improve the independence of the judiciary, considering the problem of performance of a number of government agencies that are designed to coordinate the combat against corruption, reviewing principles of financial support for law enforcement and providing measures to improve their wages.

Experiments with the model of the shadow economy revealed a number of adverse effects of its existence, which worsen the economic situation of society, undermining the foundations of morality, education and culture. Economic analysis of simulation results showed that overcoming the shadow economy is possible. 


\section{References}

Bekryashev, A.K., and Beloserov, I.P. (2000). Shadow economy and economic crime: Electronic book. Retrieved month day, year from (Russian)

Boreyko, V. (2010). Analysis of poaching in Ukraine. Retrieved February 15, 2013 from http://ecoethics. ru/analiz-brakonerstva-v-ukraine/4 (Russian)

Chernavskii, D.S., Starkov, N.I., and Shcherbakov, A.V. (2002). On the problems of physical economy. UFN, 9: 1045-1066. (Russian)

Chyzhov, O. (2010). The theoretical basis of the influence of banks and insurers to reduce shadow cash flows. Actual Problems of Economics, (9): 242-249.

Del'Anno, R. (2003). Estimating the shadow economy in Italy: A structural equation approach. Department of Economics, University of Aarhus. Retrieved June 16, 2013 from ftp://ftp.econ. au.dk/afn/wp/03/wp03_07.pdf

General Department of Civil Service of Ukraine. (2012). Employees flow report. Retrieved June 16, 2013 from http://nads.gov.ua/analytics/saw.dll?PortalPages\&_scid=QLv2gAg0BWM

Giles, D. (1999). Measuring the hidden economy: Implications for econometric modeling. The Economic Journal, 109/456: 370-380.

International Bank for Reconstruction and Development/The World Bank. (2013). Doing Business 2013. Smarter Regulations for Small and Medium-Size Enterprises. Retrieved July, 2013 from http://www.doingbusiness.org/ /media/GIAWB/Doing\%20Business/ Documents/AnnualReports/English/DB13-full-report.pdf

Kovalenko, S.O. (1999). Methodological bases of the shadow economy legalization in Ukraine. Kyiv: Znannya.

Ministry of Economic Development and Trade of Ukraine. (2012). General trend of the shadow economy in the first quarter of 2012. Retrieved February 20, 2013 from http://www.me.gov.ua/file/ link/187630/file/Shadow_Ikv2012.doc

Okhrimenko, O. (2010). Government "kicks" against the shadow economy: The limitation of cash flows? Retrieved June 16, 2013 from http://news.finance.ua/ua/ /2/0/all/2010/04/19/194140

Putnins, T., and Sauka, A. (2011). Size and determinants of shadow economies in the Baltic States. Baltic Journal of Economics, 11(2): 5-25.

Schneider, F. (2012). Shadow Economy in Turkey and in other OECD-Countries: What do we (not) know? Retrieved February 15, 2013 from http://www.gep.gov.tr/tmp/BSECpdf/Prof. Dr.FriedrichSchneiderShadEc_Turkey2012.pdf

Schneider, F., and Klinglmair, R. (2004). Shadow economies around the world: What do we know? Retrieved February 15, 2013 from http://www.crema-research.ch/papers/2004-03.pdf

Transparency International. (2012). Corruption Perception Index. Retrieved February 15, 2013 from http://www.transparency.org/cpi2012/results

Varnaliy, Z.S., and Goncharuk, A.Ya. (2006). The shadow economy: Nature, characteristics and ways of legalizing. City: National Institute for Strategic Studies. (Ukrainian)

Verkhovna Rada of Ukraine. (2011). Tax Code of Ukraine. Retrieved June 16, 2013 from http://zakon4. rada.gov.ua/laws/show/2755-17

World Economic Forum. (2012). The Global Competitiveness report 2012-2013. Retrieved June 16, 2013 from http://www3.weforum.org/docs/WEF_GlobalCompetitivenessReport_2012-13.pdf 


\title{
ŠEŠĖLINĖ EKONOMIKA UKRAINOJE: MODELIAVIMAS IR ANALIZE்
}

\author{
Igor VINNYCHUK \\ Serhii ZIUKOV
}

Černovcų Jurijaus Fedkovičiaus nacionalinis universitetas, Ukraina

Santrauka. Šiame straipsnyje analizuojamas Ukrainos šešèlinès ekonomikos mastas ir plètra. Šešèlinè ekonomika apibūdinama kaip tarpusavio santykiai, kurie vyksta ne pagal galiojančius ịstatymus ir nèra ịtraukiami ị tiesioginę ir statistinę apskaitą bei mokesčių kontrolę. Neužtikrinama valstybès institucijų veiklos kokybė, neveiksminga reguliavimo politika, mokesčių sistemos netikslumai, susiformavusi konkurencinè aplinka ir korupcija - visa tai šešèlinès ekonomikos formavimosi varomoji jèga. Straipsnyje aptariami socialiniai ir ekonominiai padariniai, kuriuos suponuoja šešèlinès ekonomikos fukcionavimas. Ekonominis-matematinis modelis buvo sukurtas siekiant identifikuoti šešèlinès ekonomikos veikimo modelius. Jis leidžia suformuluoti pasiūlymus, kokiais būdais ir priemonèmis galima sumažinti šešèlinès ekonomikos mastą Ukrainoje.

Rakšminiai žodžiai: šešèlinè ekonomika, Ukraina, korupcija. 